American Journal of Environmental Sciences 1 (1): 46-49, 2005

ISSN 1553-345X

(C) Science Publications, 2005

\title{
Vegetation Dynamics in the Tafileh Woodlands of Southern Jordan
}

\author{
Saleh Al-Qura'n \\ Department of Biology, Mu'tah University, P.O. Box 26, Karak, Jordan
}

\begin{abstract}
Woodland vegetation in the Tafileh highlands of southern Jordan was investigated and quantitatively surveyed to determine the patterns of vegetation dynamics associated with altitude and topography. Three tree species (Juniperus phoenicea L. (evergreen needle-leaved woodland resistant to cold), Pistacia atlantica Desf. and Quercus aegilps L. (cold-deciduos broad-leaved woodland) and five shrubs (Colutea istria Miller, Gomphocarpus sinaicus R. Br., Thymelaea hirsute (L.) Endl., Crataegus aronia (L.) Bosc.ex DC and Daphne linearifolia Hart.) dominate the woody vegetation in the investigated area. Lower altitudes of southwest facing slopes demonstrate generally the higher plant densities than the higher altitudes of northeast facing slopes. Species segregation occurs on the basis of community ecological importance value depending on altitudes, slopes and human impact factor through grazing activities, wood gathering especially on plateau sites. Regeneration consequently negatively affected due to continuous reduction in species diversity and tree size distribution.
\end{abstract}

Key words: Woodland, Vegetation, Phytogeography, Importance Value, Regeneration

\section{INTRODUCTION}

Jordan lies between longitudes $35^{\circ} 40^{\prime}$ and $39^{\circ} \mathrm{E}$ and between latitudes $29^{\circ} 30^{\prime}$ and $34^{\circ} \mathrm{N}$ in the transition region between zonobiome (with moist cold winters and dry hot summers) and the arid one. Jordan is of great interest in vegetation ecology because it is the meeting place of the Mediterranean, Irano-turanian and Saharo arabian regions or the Holarctic kingdom and the Nubo-sindian region of the palaeotropicl kingdom [1]. For this reason there are conspicuous changes in the vegetation and in the composition of the flora over relatively short distances (within $30 \mathrm{~km}$ on the western slopes of the border mountains). Tafileh mountain lies in the southern part of Jordan and has the highest highlands which supports the growing of forests and woodland vegetation, since of its unique climate and topography [2-4].

Although Tafileh mountain is dominated by the vegetation of the mediterranean phytogeographical element, but the presence of a mixture of other phytogeographical elemens is recorded within certain narrow slope strips especially which extended to the west towards the Jordan rift valley [5].

During the tertiary period, upheaval of mountains in the middle east brought about not only the physiographical segregation, but gave rise as well to climatic differentiation which serves to stimulate the diversity of plant species in highland areas [6].

In the investigated area, Juniperus phoenicea L., Pistacia atlantica Desf. and Quercus aegilops L. trees dominate the woodland vegetation where trees are festooned or sculptured with lichen species, while different fungus species are distributed on the ground below and it is speculated that the Tafileh mountains may have been the center of origin for these species from which it migrated to the lower peripheral regions south or west or even to the north [5,7].

The study area is located $20 \mathrm{~km}$ south of Tafileh city in $\mathrm{Al}$ ata'ta mountain near Dana within Tafileh highlands at an elevation from 900-1500 $\mathrm{m}$ above the sea level. This area is dominated by sub humid and zonobiome conditions since it is influenced by the westerly and northerly fronts' currents associated with winter precipitation, so the cold snowy winter is the general climate. The mean annual precipitation is of $450 \mathrm{~mm}$ in winter while the spring months tend to be wetter with average precipitation about $150 \mathrm{~mm}$. The mean summer temperature is $24^{\circ} \mathrm{C}$ while from $2-6^{\circ} \mathrm{C}$ is the average winter temperature. The mean evapotranspiration rates are $1300 \mathrm{~mm} /$ year. The ridges in the highlands are remnants of the lime stones and to a lesser extent with metamorphosed intrusive. Massive undifferentiated sand stones (so-called Nubian sand-stones of the Cambrian formation are dominant. Lime stones and dolomites, chalky marls and clays of the cenomanian and santonian-turonian $[8,9]$.

The soil parent material consists of metamorphic rocks with 6.5-7.0 pH, the soil texture ranges from loamy silt to silt clay to gravel clay. The first $15 \mathrm{~cm}$ often produces an average of $10 \%$ organic matter indicating the favorable climatic conditions for plant growth and development.

It is clear for long period of time, inhabitants and residents have largely impacted adjacent woodlands by different ways and methods to get pasture, timber for fuels and building materials and implements which give a real evidence that these pressures influenced by the 
human have helped to bring about a shift of middle eastern woodland to the north and west, which make the regeneration also been seriously curtailed $[3,10]$.

In recognizing the importance of Tafileh highlands, the government of Jordan began early in 1970's, to develop the national forestation stations in different regions and later to establish the wildlife reserve in Dana to embrace the altitudinal life zones and the wealth of Tafileh habitats.

It is worthful to say that the quantitative surveys in the Tafileh woodlands in form of concrete representative data is very important which might be helpful in characterizing the vegetation type dominated within the investigated area for the benefits of human whose the center of the ecosystem.

\section{MATERIALS AND METHODS}

Two sampling methods were used to investigate the major habitat types represented within the study area including lower and higher elevations, slope aspects (north-east and south-west facing slopes) and plateau sites [10, 11].

The point-center quarter sampling method was used to collect the tree data. Points were chosen, $20 \mathrm{~m}$ between every two successive points and a compass bearing was used to establish a line of direction for each transect, 40 $\mathrm{m}$ between every two parallel transects. In each stand from four transects, a total of 40 trees per habitat type was evaluated. A grand total of 200 trees were recorded for density while measured for diameter approximately $1.30 \mathrm{~m}$ above the ground surface to the breast level as the standard height for trees' trunks [12-15].

The line-intercept sampling method was used in collecting shrub data. Twenty five line strips were established per stand for a grand total of 100 line strips, each $50 \mathrm{~m}^{2}$ in area. Forty meters separated the parallel transects. Data collected included plant density, frequency and coverage for all shrub species. These data were in turn converted into relative values and summed to calculate the community ecological Importance Value Indices (IV), which can be calculated simply as summation of the Relative Density (RD), the Relative Frequency (RF) and the Relative Coverage (RC). Behavior Indices (BI) also calculated (relative coverage $\mathrm{x}$ relative frequency) were used to provide an indication of the extent to which a species may increase or decrease in dominance. RD can be calculated by dividing the number of the individual's of the species on the total number of the individual's of all species. RF can be calculated by dividing the frequency of the species on the total frequencies of all species. RC can be calculated by multiplying the area covered by the species depending on its diameter from the Tables present [11] by the absolute density (RD $x$ total density), the result then divided on the number of the individual's of the species $[16,20]$.

\section{RESULTS AND DISCUSSION}

It is obvious after data analyses of the woody species measurements collected for 3800 woody plants, that Tafileh woodlands were dominated by three trees and five shrubs' species (Table 1). Juniperus phoenicea L. is the most dominant tree species while Thymelaea hirsuta (L.) Endl. is the most dominant shrub species within the investigated woodland strata.

Table 1:Values of Ecological Survey of Major Perennial Species in Tafileh Woodland Related to RDi*, $\mathrm{RFi}^{*}, \mathrm{RCi}^{*}, \mathrm{IVi}^{*}$ and $\mathrm{BIi}^{*}$

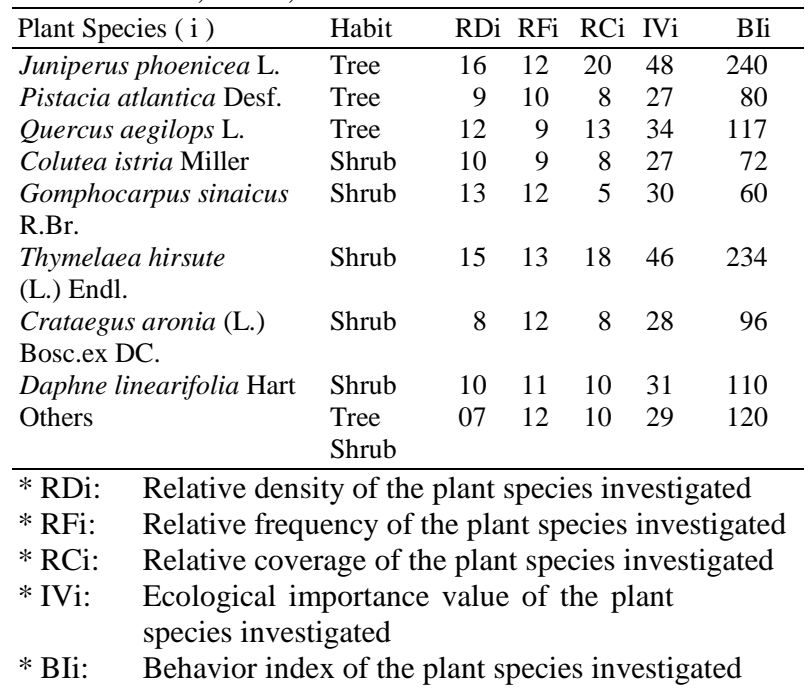

During the ecological investigation, the most herbal composition of the plant vegetation cover observed (although not included within the survey) was consist of: Reichardia tingitana (L.) Roth., Aegilops kotschi Boiss, Centaurea iberica Trev., Plantago afra L., Euphorbia hierosolymitana Boiss, Lecokia cretica (Lam.)DC., Poa bulbosa L. and Gagea reticulata (Pall.) Schult [1-3, 5, 7].

By looking to the data collected from the ecological survey (Table 2 and 3 ) of the investigated community, it is very clear to see the plant species segregate with relative to the elevation and slope aspects. The ecological importance values variate within Tafileh woodland accordingly; plant densities of the investigated north-east slopes differ from that of the south-west slopes (slopes involved range from 10-25 in angle), also the elevations above the sea level within the slope facing destinations reflected distinctive kind of variations (elevations involved range from 900-1500 $\mathrm{m})$. It is possible to say in general, the plant density decreases on the north-east slopes of higher elevation and on the plateau sites, while the lower elevations of the south-west facing slopes have the highest plant 
American J. Environmental Sci., 1 (1): 46-49, 2005

Table 2: Distribution of the Ecological Importance Values Related to the Elevation and Slope Aspects

\begin{tabular}{|c|c|c|c|c|c|}
\hline \multirow[t]{2}{*}{ Plant species } & \multicolumn{2}{|c|}{ Northeast slopes } & \multicolumn{2}{|c|}{ Southwest slopes } & \multirow{2}{*}{$\begin{array}{l}\text { Plateau } \\
1500 \mathrm{~m}\end{array}$} \\
\hline & $900-1200 \mathrm{~m}$ & $1200-1500 \mathrm{~m}$ & $900-1200 \mathrm{~m}$ & $1200-1500 \mathrm{~m}$ & \\
\hline Juniperus phoenicea L. & 28 & 18 & 65 & 13 & 10 \\
\hline Pistacia atlantica Desf. & 24 & 13 & 20 & 8 & - \\
\hline Quercus aegilops L. & 30 & 14 & 18 & 11 & 8 \\
\hline Colutea istria Miller & 13 & 10 & 11 & 13 & - \\
\hline Gomphocarpus sinaicus R.Br. & 40 & 20 & 39 & 10 & 20 \\
\hline Thymelaea hirsuta (L.)Endl. & 48 & 37 & 27 & 15 & 16 \\
\hline Crataegus aronia (L.)Bosc.ex DC & 20 & 28 & 24 & 20 & 28 \\
\hline Daphne linearifolia Hart & 30 & 19 & 18 & 16 & 38 \\
\hline
\end{tabular}

Table 3: Estimated Tree and Shrub Densities (per/ha) by Habitat Types of Tafileh Woodlands

\begin{tabular}{ll}
\hline Habitat type & Estimated density (per/ha) \\
\hline North-east slopes & 6622 \\
South-east slopes & 7390 \\
Plateau sites & 6010 \\
Lower elevation slopes & 8520 \\
Higher elevation slopes & 6018 \\
\hline
\end{tabular}

Table 4: Distribution of Diameter Measurements of Juniperus phoenicea L.boles Surveyed in the Tafileh Woodland in Al-ata'ta Mountain near Dana

\begin{tabular}{lcccccc}
\hline & & Percent distribution \% & & \\
Habitat type & $\begin{array}{l}\text { Mean density } \\
\text { (per/ha) }\end{array}$ & $-1-23 \mathrm{~cm}$ & $24-39 \mathrm{~cm}$ & $40-55 \mathrm{~cm}$ & $56-71 \mathrm{~cm}$ & $72-87 \mathrm{~cm}$ \\
\hline North-east slopes & 120 & 10 & 37 & 34 & 15 & 04 \\
South-west slopes & 225 & 28 & 42 & 30 & 00 & 00 \\
Plateau & 95 & 13 & 42 & 42 & 11 & 02 \\
Lower elevation & 230 & 16 & 44 & 48 & 12 & 00 \\
Higher elevation & 115 & 12 & 32 & 32 & 10 & 00 \\
General woodland & 145 & 14 & 42 & & & 02 \\
\hline
\end{tabular}

densities (Table 2 and 3).

It is obvious from the results obtained (Table 1 and 2), the plant density and coverage increases on the lower elevation slopes compared with the higher elevation slopes, while the species composition and the importance value are approximately more similar in higher elevation slopes than the lower elevation slopes. In general, the tendency of behavior index for the woodland species examined show some kind of variation: Juniperus phoenicea L., Pistacia atlantica Desf., Quercus aegilops L., Gomphocarpus sinaicus R. $\mathrm{Br}$, Thymelaea hirsute (L.)Endl. and Daphne linearifolia Hart have the tendency to increase on lower elevation slopes, while Colutea istria Miller and Crataegus aronia (L.)Bosc.ex DC have the tendency of behavior index to increase on higher elevation slopes.

It is worthy to recognize after the analysis of the data obtained in Table 2, the presence of certain woodland species more important in specific habitats, Pistacia atlantica Desf., Quercus aegilops L., Thymeleae hirsuta (L.) Endl. and Daphne linearifolia Hart species are increasing in dominance on north-east facing slopes, while the major increasing in dominance on south-west facing slopes occur to Juniperus phoenicea L., southwest facing slopes also support some scattered densities of some vegetation cover species not included within the study, these species are representing mainly: Diplotaxis hara (Forsk.)Boiss, Astragalus spinosus (Forsk)Muschl., Teucrium polium L., Phlomis viscosa Poirt and Ballota undulata (Sieb.ex Fresen.)Benthem. The absence of Pistacia atlantica Desf. and Colutes istria Miller is the major distinctive character of the plateau vegetation, although these two species are considered from the most important members of the Tafileh woodland vegetation (Table 2 ).

By analysis of the data obtained in Table 4 concerning the diameter measurements collected from 200 Juniperus trees in the study as indicated previously in materials and methods' section, the results quite clearly show that most of the trees and shrubs'boles fall within $24-55 \mathrm{~cm}$ category $(66-82 \%)$ and here it is very important to clerify that, even the diameter measurements collected by different investigators for the same woodland species may vary among them and this is simply because it depends how the investigator does take the measurements, either collected at the ground level, or above the ground surface as collected here in this study at $1.30 \mathrm{~m}$ height above the ground surface (at breast level) and therefore the results obtained do not correlate with each others [16-20].

Generally, the higher elevation in all habitat types and facing slopes show a wider range of diameter classes 
than the lower elevation, although in most cases, their densities are extremely lesser (equal a half) of what exist in the lower elevation (Table 4).

Southwest facing slopes show a $50 \%$ increase in Juniperus density over the northeast facing slopes and a $38 \%$ increase over the plateau stands and doubtless, most of this increase is occurring in the lower elevation (900-1200 m).

It is very clear from the results and observations obtained from the field; the soil erosion, climate and the human intervention through wood gathering and livestock grazing, are the most important factors which influence the vegetation dynamics in the Tafileh woodland and these factors are similar to those influence any vegetation dynamics in the middle east area appointed at by many investigators $(5,10)$, consequently, the understoy is dominated by unpalatable and toxic species which have increased especially under the grazing pressure particularly from the goat herds.

The utilization of seedlings by grazing animals and the collection of Juniperus fruits to be used in tanning industry of animal skins are influencing the tree densities negatively. So under the climatic conditions exist in the Tafileh mountains, one could expect densities at least of 400-600 trees per ha, which was not occur although Juniperus phonicea L. is usually considered from the most prolific producers of viable seeds.

Brooks et al. [10] considered the invariability of Juniper is associated with incidence of fog and moist. In the Tafileh mountains, it is the south-west and west facing slopes which receive the full impact of the winddriven fog formed. It is probable that increased Juniper importance on these slopes reflects the influence of this climatic factor coupled with incidence of radiation. Cool air drainage flows during nights of summer from the heights to the lower elevation slopes making the availability of standing water to stimulate plant growth. So the desiccating influence of wind as well as surface temperatures of bare soils are minimized in the lower elevation habitats.

\section{CONCLUSION}

From the above results and discussions obtained, it is concluded that the importance value of the ecological community is influenced by the topography and elevation, which increases in the southwestern highlands of Tafileh mountains and therefore supports the segregation of woodland vegetation components.

The intervention of human activities play a major role in influencing the vegetation dynamics through wood gathering and livestock grazing resulting most oftenly in increasing the dominance percentage of understory species of unpalatable or toxic ones, which consequently reduces the densities of woodland species under investigation.

At the end, under these pressure conditions, regeneration has not the ability to substitute the loss and to increase the species diversity, unless the getting rid of suppressing factors.

\section{REFERENCES}

1. Zohary, M., 1973. Geobotanical Foundations of the Middle East. Gustav. Fisher Verlag, Stuttgart.

2. Al-Eisawi, D., 1982. List of Jordan Vascular Plants. Jordan University, Amman.

3. Boulos, L., 1978. Flora of Jordan: An introduction to the wildlife of the Hashemite Kingdom of Jordan. Candollea, 41: 61-70.

4. Karim, F., and S. Al-Qura'n, 1988. Wild Flowers of Jordan. Yarmouk University Press, Irbid, Jordan.

5. Zohary, M. and N. Feinbrun-Dothan, 19661686. Flora Palaestina. Jerusalem.

6. Bender, F., 1974. Geology of Jordan. Berlin, Stuttgart.

7. Karim, F., and S. Al-Qura'n, 1986. Medicinal Plants of Jordan. Yarmouk University, Irbid, Jordan.

8. Annual Reports of the Metrological Department of Jordan, 1990-2003. Amman, Jordan.

9. Burdon, D., 1959. Geology of Jordan (FAO) and Government of Jordan, Amman.

10. Brooks, W.H. and K.S.D. Mandit, 1983. Vegetation dynamics in the Asir woodlands of southwestern Saudi Arabia. J. Arid Environ., 6: 357-367.

11. Brower, J.E., J.H. Zar and C.N. Von Ende, 1990. Field and Laboratory Methods for General Ecology. Wm.c. Brown Publishers.

12. Canfield, R., 1941. Application of the line interception method in sampling range vegetation. J. Fores., 39: 338-394.

13. Dileou, E.C., 1977. Mathematical Ecology. John Wiley and Sons, New York.

14. Dix, R.L., 1961. An application of the pointcentered quarter method to the sampling of range land vegetation. J. Range Management, 14: 63-69.

15. Greig-Smith, P., 1963. Quantitative Plant Ecology. $3^{\text {rd }}$ Edn. University of California Press, Berkely. Calif.

16. Landers, P.B., P. Morgan and F.J. Swanson, 1999. Overview of the use of natural variability concept in managing ecological systems. Ecol. Applications, 9: 1179-1188.

17. Lorimer, C.G., 1985. Methodological considerations in the analysis of forest disturbance history. Canadian J. forest Res., 15: 200-213.

18. Mueller-Dombois, D. and H. Ellenberg, 1974. Aims and Methods of Vegetation Ecology. John Wiley and Sons, New York.

19. Risser, P.G. and P.H. Zelder, 1968. An evaluation of the grassland quarter method. Ecology, 49: 1006-1009.

20. Wong, C.M. and K.P. Lertzman, 2001. Errors in estimating tree age: Implication for studies of stand dynamics. Canadian J. Forest Res., 31: 1262-1271. 